\title{
Advances in lens implant technology
}

\section{Daniel Kook ${ }^{1 *}$, Anselm Kampik ${ }^{1}$, Alois K. Dexl ${ }^{2}$, Nicole Zimmermann ${ }^{3}$, Adrian Glasser ${ }^{4}$, Martin Baumeister ${ }^{5}$ and Thomas Kohnen ${ }^{5}$}

\author{
Addresses: ${ }^{1}$ Department of Ophthalmology, Ludwig Maximilians University Munich, Germany; ${ }^{2}$ Department of Ophthalmology, Paracelsus \\ Medical University Salzburg, Austria; ${ }^{3}$ Max Planck Institute of Psychiatry, Chaperone Research Group, Munich, Germany; ${ }^{4}$ University of Houston, \\ College of Optometry, Houston, United States; ${ }^{5}$ Department of Ophthalmology, Johann Wolfgang Goethe University, Frankfurt am Main, \\ Germany \\ * Corresponding author: Daniel Kook (daniel.kook@med.uni-muenchen.de) \\ Fl000 Medicine Reports 2013, 5:3 (doi:10.34I0/M5-3) \\ This is an open-access article distributed under the terms of the Creative Commons Attribution-Non Commercial License \\ (http://creativecommons.org/licenses/by-nc/3.0/legalcode), which permits unrestricted use, distribution, and reproduction in any medium, \\ provided the original work is properly cited. You may not use this work for commercial purposes. \\ The electronic version of this article is the complete one and can be found at: http://fl 000 .com/prime/reports/m/5/3
}

Abstract
Cataract surgery is one of the oldest and the most frequent outpatient clinic operations in medicine
performed worldwide. The clouded human crystalline lens is replaced by an artificial intraocular lens
implanted into the capsular bag. During the last six decades, cataract surgery has undergone rapid
development from a traumatic, manual surgical procedure with implantation of a simple lens to a
minimally invasive intervention increasingly assisted by high technology and a broad variety of implants
customized for each patient's individual requirements. This review discusses the major advances in this
field and focuses on the main challenge remaining - the treatment of presbyopia. The demand for
correction of presbyopia is increasing, reflecting the global growth of the ageing population. Pearls
and pitfalls of currently applied methods to correct presbyopia and different approaches under
investigation, both in lens implant technology and in surgical technology, are discussed.

\section{Introduction}

Age-related cataract is the leading cause of severe visual impairment today. The term "cataract" means "waterfall" and derives from the Latin word "cataracta" and the

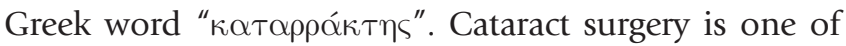
the oldest surgical procedures, and with approximately 15 million performed annually, it is one of the most frequent outpatient clinic surgeries in medicine performed worldwide [1]. Risk factors for developing cataract include older age, history of diabetes mellitus, steroid intake, smoking, female gender, myopia, higher hemoglobin A1c and higher systolic blood pressure [2-5]. Signs of the increasing opacity of the crystalline lens, which usually become clinically significant within the $6^{\text {th }}$ or $7^{\text {th }}$ decade of life, include blurry vision, fading colour perception, glare, poor night vision, double vision and prescription changes of eyeglasses. As no study to date has shown any clear advantage from nutritional or pharmacological treatment [6], surgical removal of the crystalline lens remains the only effective option for restoring visual function. The first cataract surgeries date back to around $800 \mathrm{BC}$ performed in Greece and India. Until the $18^{\text {th }}$ century, cataracts were couched with the surgeon simply inserting a needle in the eye and pushing the lens into the anatomical space behind the crystalline lens, the vitreous cavity [7]. Thus, the visual axis was cleared of the opacity, but the eye was left with a large refractive deficit, allowing the patient to see only blurry shapes. In addition, complications and infection rates were high. In 1747, the French surgeon Jacques Daviel published the first account of a cataract extraction through an incision rather than simply displacing the lens. During the following two centuries, cataract surgery further improved with introduction of local anaesthesia, aseptic technique and specialized instrumentation. However, until the middle of the $20^{\text {th }}$ century, patients were still required to wear unattractive high-powered spectacles postoperatively because the eyes were left without an intraocular lens. In 1949, the British surgeon Sir Harold Ridley started the development of intraocular lens with 
Figure I. Intraoperative snapshot with an intraocular lens

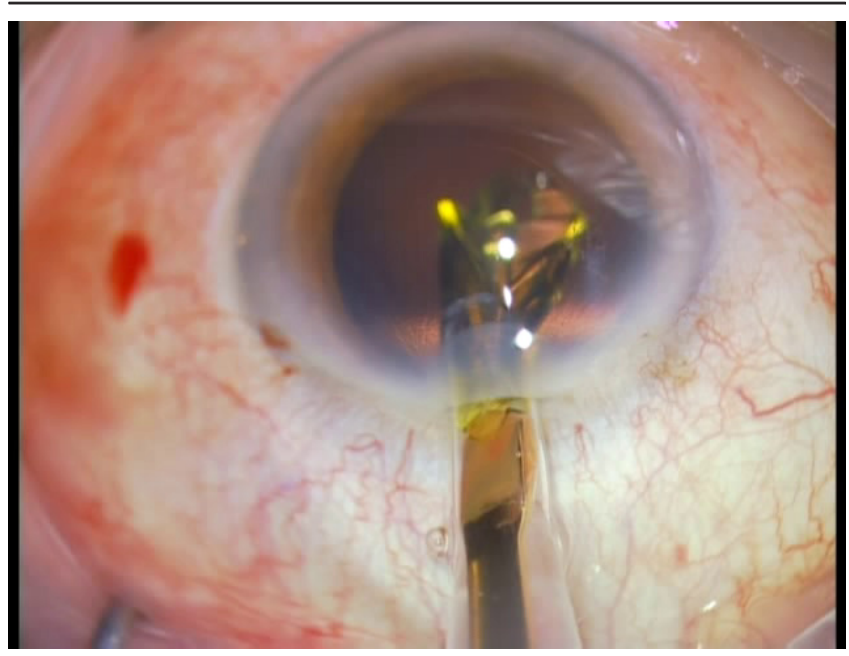

Intraoperative snapshot of injecting a foldable, one-piece, monofocal intraocular lens (AcrySof IQ, Alcon) into the capsular bag.

the first implantation of a polymethylmethacrylate (PMMA) lens into a human eye after cataract extraction [8]. With the invention of lens extraction by ultrasound emulsification (phacoemulsification) in 1967 by Charles Kelman [9], and the development of foldable intraocular lenses, cataract surgery could now be conducted through incisions of $3 \mathrm{~mm}$ or less, which greatly reduced perioperative morbidity. Today's foldable intraocular lenses are made of hydrophobic or hydrophilic acrylate or, less commonly, silicone, and consist of an optic of usually $6 \mathrm{~mm}$ and two intraocular lens-haptics that contribute to a total diameter of $11-13 \mathrm{~mm}$ when unfolded (Fig. 1). Intraocular lenses are generally injected into the capsular bag, the anatomic envelope of the crystalline lens, via an injector system, through a small incision in the peripheral cornea.

\section{Recent advances that have resolved problems Posterior capsule opacification}

One major problem of older intraocular lenses was an early and severe postoperative opacification of the capsular bag (Fig. 2a). Both modern surgical techniques and also materials and designs of modern intraocular lenses, especially a 360 degree "sharp edge" of the posterior optic, significantly lowered the rate of posterior capsule opacification today by inhibiting postoperative migration of remaining lens epithelial cells on the posterior capsule (Fig. 2b) [10-13]. If posterior capsule opacification does occur, it is easily treated with yttrium aluminum garnet (YAG) laser capsulotomy.
Figure 2. Biomicroscopic and scanning electron micrograph images of an intraocular lens
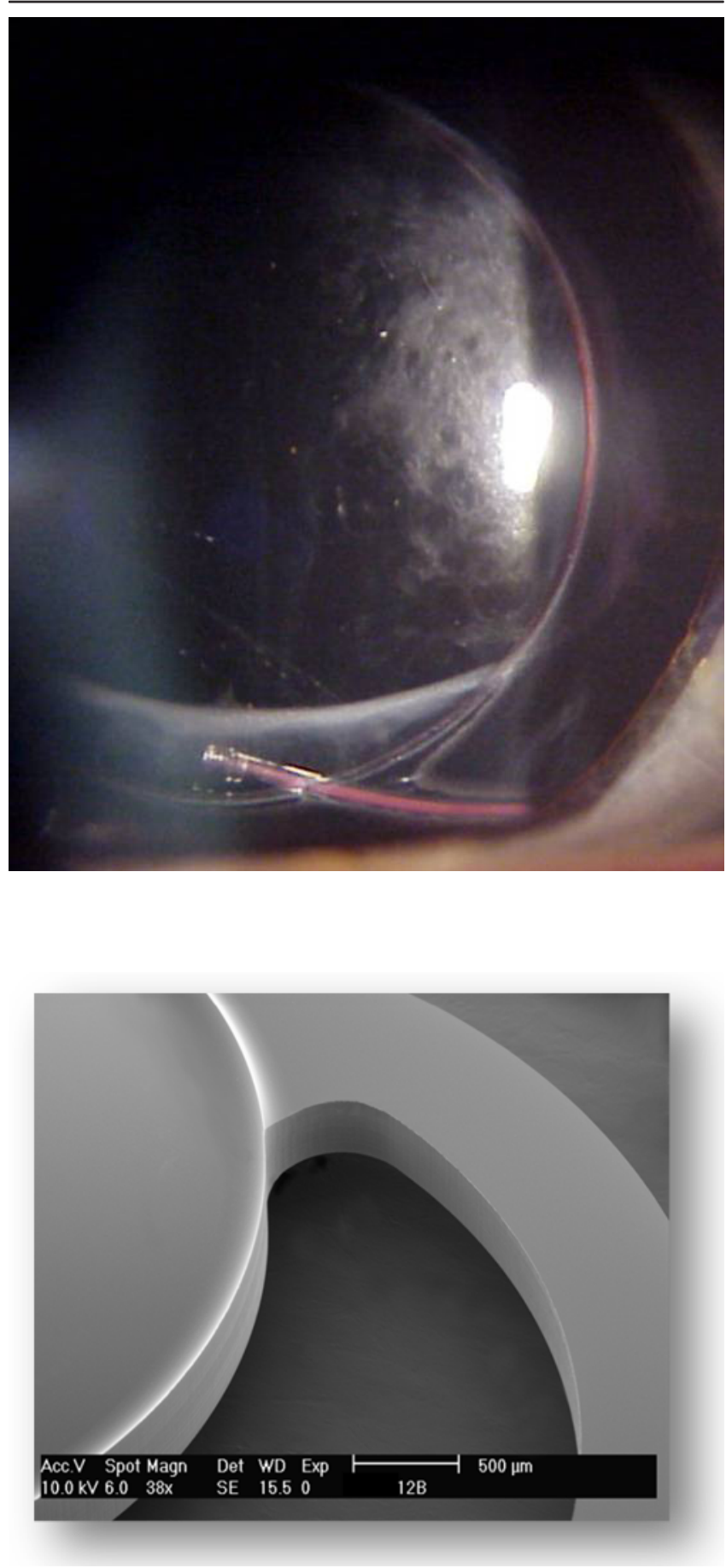

a) Biomicroscopic image of posterior opacification of the capsular bag 12 months after implantation of an intraocular lens.

b) Scanning electron micrograph image of the sharp edge of the posterior optic of an intraocular lens for the prevention of posterior capsule opacification. 


\section{Surgically induced astigmatism}

With the steadily increasing miniaturization of surgical instruments in the last few decades, incision sizes decreased accordingly, so that, today, cataract surgery can be performed using incisions of less than $1.5 \mathrm{~mm}$. The smaller the corneal incision, the less the effect on the corneal geometry after surgery. Modern, foldable intraocular lenses can be injected via injector systems through incisions of between 1.6-1.8 mm.

\section{Corneal astigmatism}

About one third of all patients undergoing cataract surgery have a corneal astigmatism of more than 1.0 diopters $(\mathrm{dpt})$ [14]. The invention of toric intraocular lenses that have different refractive power in two orthogonal meridians allowed the correction of even higher regular corneal astigmatisms. As the first toric intraocular lenses suffered from unacceptable postoperative rotation within the capsular bag and according loss of astigmatic correction [15], modern toric intraocular lenses show a very good rotational stability of less than 5 degrees, due to improvements in design and sizing of the implants (Fig. 3) [16-18].

\section{Spherical aberration}

Spherical aberration is an optical effect that occurs due to an increased refraction of light that passes the periphery of an optical medium like the cornea or lens, in contrast to light that passes its center. The invention of aspheric intraocular lenses with negative asphericity allowed correction of the usually positive spherical aberration of the natural human cornea. If corneal asphericity is measured

Figure 3. Image of a bifocal toric intraocular lens

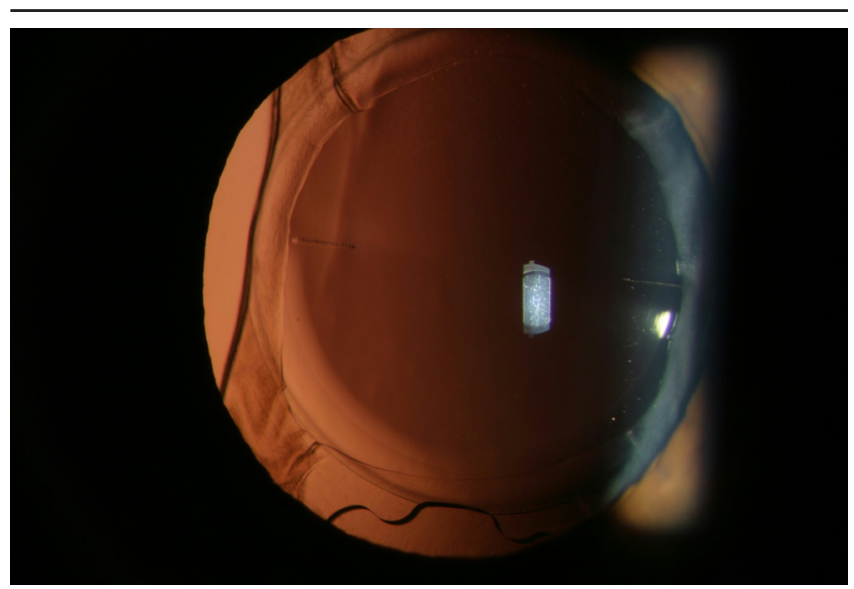

Image of a bifocal toric intraocular lens (Lentis MF 30, Oculentis) with markings on the intraocular lens optic indicating the axis of the torus that has to be aligned with the steep meridian of the astigmatic cornea intraoperatively. preoperatively, customized correction of the corneal spherical aberration via a correspondent selection of aspheric intraocular lenses can improve postoperative visual quality, especially in younger patients with larger pupil diameters [1,19].

\section{Postoperative modification of intraocular lens power}

Modern preoperative optical biometry of the eye, together with refined modern formulas, allows very accurate calculation of the intraocular lens to be implanted. However, there is still the risk of a postoperative refractive error, especially in highly myopic or highly hyperopic eyes. In order to address this problem, the light adjustable lens has been developed. The light adjustable lens allows modification of the refraction up to $2.25 \mathrm{dpt}$ in spherical shapes and $-2.75 \mathrm{dpt}$ in cylindrical shapes via UV-irradiation of intraocular lenses made of partially polymerized silicone within one to three weeks of surgery [20].

\section{Presbyopia - pearls and pitfalls of today's clinical approaches}

The most common method of correcting presbyopia (farsightedness) is reading glasses. The major challenge in cataract surgery today is the surgical treatment of presbyopia. Accommodation (focussing between distant and near objects) in the young human eye occurs by contraction of the ciliary muscle, which releases zonular tension and allows the capsular bag around the crystalline lens to mould the lens into an accommodated form. The crystalline lens thereby increases its refractive power by changing into a more spherical shape (Fig. 4) [21].

Presbyopia occurs because the ageing crystalline lens within the capsular bag gradually increases in stiffness [22-24]. Therefore, despite that the ciliary muscle still contracts in an effort to accommodate the presbyopic eye, the crystalline lens is not able to undergo accommodative changes in shape any more [25]. This loss of accommodation usually becomes clinically manifest in patients by their mid 40s. Further, removal of the crystalline lens for cataract surgery also necessarily results in a complete loss of accommodation. To address this problem, different approaches are currently implemented in the clinic.

\section{Monovision}

In monovision, one eye (usually the dominant eye) is corrected for distance (emmetropic) and the other eye for near with a monofocal intraocular lens, leaving the eye slightly nearsighted (myopic) between -1.00 and $-2.00 \mathrm{dpt}$ [26]. Disadvantages of this method are loss of distance visual acuity, depth perception and stereo vision. 
Figure 4. Schematic illustration of the accommodated state of the crystalline lens
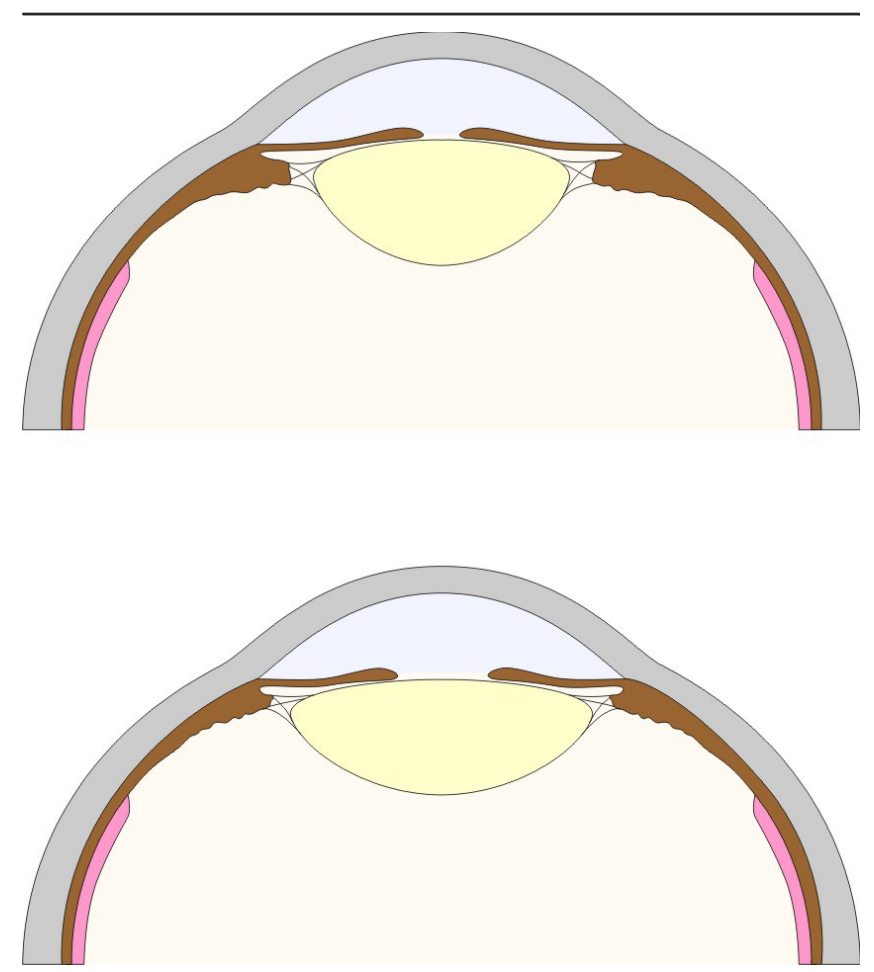

Schematic illustration of the accommodated state of the crystalline lens with "near" focus (above) and of the unaccommodated state with distant focus (below). During accommodation, the shape of the lens is more spherical, resulting in a higher refractive power.

\section{Multifocal intraocular lenses}

These intraocular lenses have a specially designed optic with either a refractive or diffractive (or both) bi- or trifocality, so that the rays of light are divided into two or more foci, providing some independence from reading glasses (Fig. 5). Disadvantages of these lenses are reduction in quality of vision, especially loss of contrast sensitivity, creation of glare and halos, and reduced intermediate visual acuity $[27,28]$.

\section{Accommodating intraocular lenses}

These intraocular lenses are of many different conceptual designs, including flexible haptics, mouldable gels, and fluid displacements, with either single monofocal intraocular lenses, dual intraocular lenses or gel-filled lenses. In theory, these intraocular lenses restore accommodation by movement ("optic shift") or a change in surface curvatures of the intraocular lenses within the capsular bag, theoretically resulting accommodative amplitudes of between 0.5 and $5 \mathrm{dpt}$. Single optic or dual optic intraocular lenses that are based on an anterior shift may have a maximum capacity to produce up to
Figure 5. Image of a bifocal intraocular lens

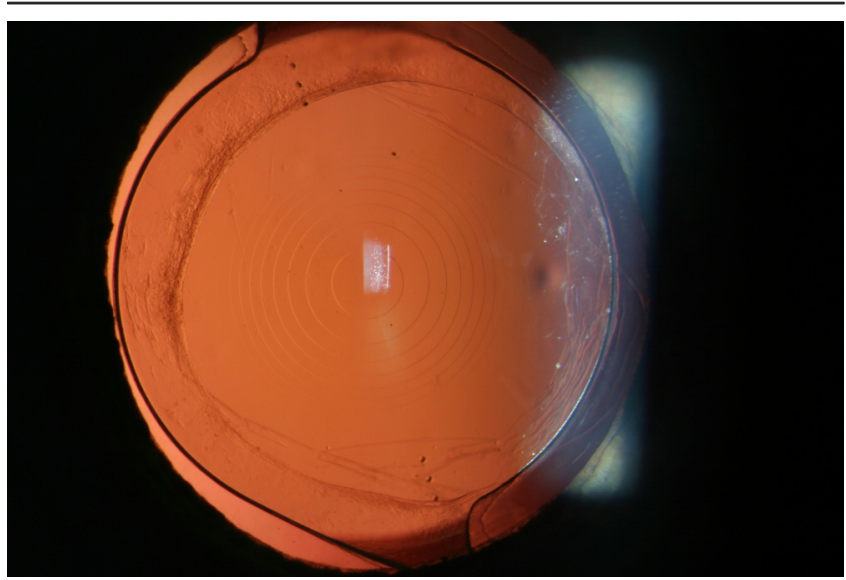

Image of a bifocal intraocular lens (AcrySof ReSTOR DI, Alcon). Within the optic, nine rings are incorporated that result in diffraction of the light into a distant and a near focus. This intraocular lens is also a toric model as one can see at the markings in the periphery of the optic.

Figure 6. Schematic image of an accommodating intraocular lens with a monofocal optic and specially designed haptics

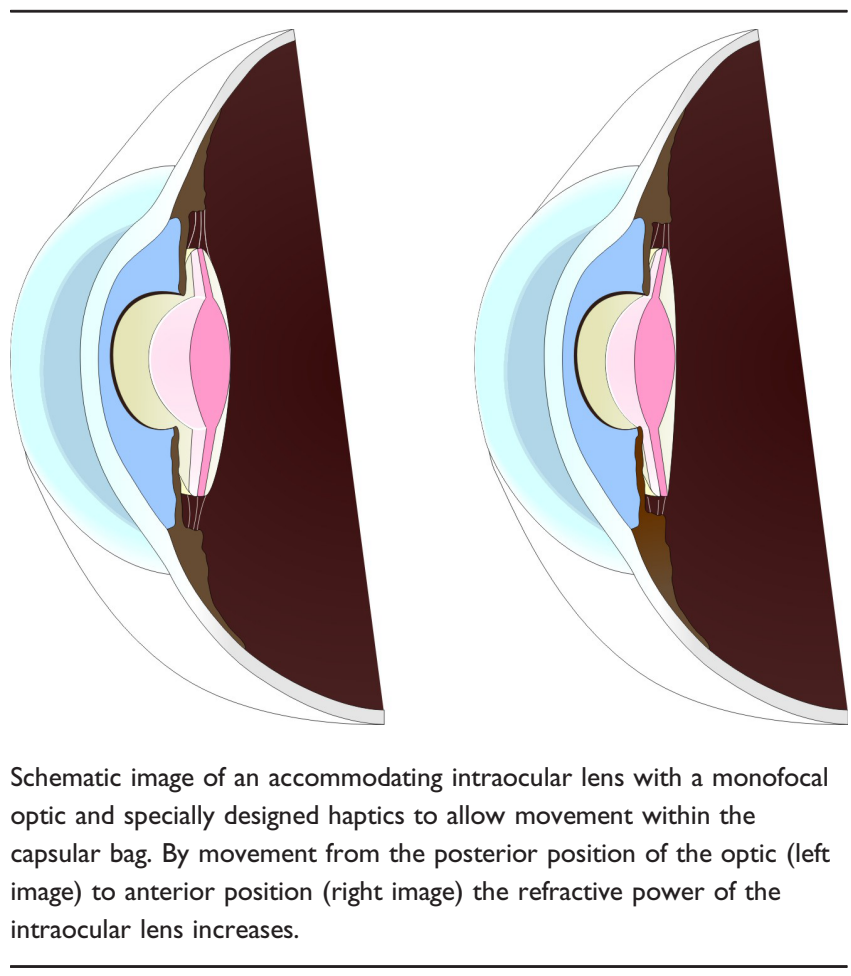

$1 \mathrm{~mm}$ of movement, which theoretically could produce $\sim 1 \mathrm{dpt}$ of accommodation for single optic intraocular lenses or $\sim 2.5 \mathrm{dpt}$ of accommodation for dual optic intraocular lens (Fig. 6) [29-31]. 
In reality, to date, there is a lack of proof of efficacy of this approach under physiologic conditions because of postoperative progressing fibrosis of the capsular bag, which inhibits intraocular lens movement $[32,33]$.

\section{Scientific approaches for the treatment of presbyopia}

Given the lack of good options for the correction of presbyopia, presbyopia still represents a formidable clinical challenge and it is therefore seen as the "holy grail" in cataract and refractive surgery. In the quest for this grail, a lot of research on surgical techniques and intraocular lens technologies for presbyopia is currently in progress.

\section{Femtosecond laser-assisted cataract surgery}

Ultrashort-pulse femtosecond lasers have been developed to increase precision of, and to minimize collateral damage in, ocular surgery. Usage of a femtosecond laser on a human cornea was first described in 1994 [34]. Now, femtosecond lasers are increasingly implemented in cataract surgery, and reported benefits include higher precision of the anterior opening of the capsular bag and reduced ultrasound power needed during phacoemulsification because of the prior laser-induced fragmentation of the crystalline lens [35-37]. Femtosecond laser-generated capsulotomies have also been shown to display greater regularity and a more precisely controlled shape, size and centration of the capsulotomy, which may improve the functional outcomes of multifocal intraocular lenses or accommodating intraocular lenses $[38,39]$. However, this technique is not able to eliminate the mentioned specific drawbacks of multifocal intraocular lens or accommodating intraocular lens. In addition, as with any new technique, femtosecond-laser assisted cataract surgery involves a learning curve for the surgeon and is not free of complications [40].

\section{Lens softening}

Treating the crystalline lens in presbyopic eyes without inducing significant opacity of the lens by photodisruption with a high-power pulsed laser is a concept that was proposed in 1998 to reduce the stiffness of the crystalline lens $[41,42]$. Today, several teams are further investigating this approach using the femtosecond laser [43-45].

\section{Lens refilling}

Lens refilling of the capsular bag with gel-like polymers that mimic the crystalline lens in terms of refractive index, transparency and viscoelastic behaviour in order to substitute for the crystalline lens is an appealing technique for the correction of presbyopia (Fig. 7) [46-48]. It draws on the well-founded theory of accommodation and aims to correct refractive errors and restore accommodation.

However, there are several problems regarding this concept. Maintaining integrity of the capsular bag is one critical point. To avoid optical distortions, opening of the capsule must be performed in the periphery of the lens capsule, and instead of a traditional $5 \mathrm{~mm}$ capsulotomy, lens refilling needs a small-diameter peripheral capsulotomy. Lens extraction has to be performed via this small opening. An additional practical challenge is the delivery of the polymer into the capsular bag without any leakage during or after implantation. Controlling refraction is also difficult and requires intraoperative measurement of ocular refraction to avoid unintentional under- or overfilling. Finally, the most important hurdle in the development of lens refilling is the need to completely avoid postoperative proliferation of lens epithelial cells leading to posterior capsule opacification, which inhibits changes in shape of the capsular bag. Laser-assisted opening of the posterior capsule is not possible in lens refilling because of the leakage of the polymer that would result after this procedure.

\section{Pharmacologic inhibition of postoperative capsular opacification}

As posterior capsule opacification is caused by proliferation and migration of residual lens epithelium cells after surgical removal of the lens, several pharmacologic agents have been under investigation, and others are in development, to attempt to address this problem. For lens refilling strategies, posterior capsule opacification and also anterior capsular opacification may be a problem.

One strategy is to lavage the capsular bag intraoperatively with cytotoxic agents or hyper/hypo-osmotic solutions, thereby destroying lens epithelium cells. Another option is to use an intraocular lens that functions as a postoperativecontrolled drug release implant, e.g. by coating the intraocular lens with pharmacologic agents. In both intraand postoperative applications of these substances, avoidance of leakage of the cytotoxic agents into the adjacent intraocular anatomical structures is mandatory, as this could have a devastating effect on other ocular tissues.

\section{Summary}

During the last 60 years, cataract surgery has undergone a rapid development from a traumatic, solely manual surgical procedure with implantation of an intraocular lens to a minimal invasive operation increasingly assisted by advanced technology and a wide range of different intraocular lenses customized for each patient's individual requirements. The last challenge in modern intraocular lens technology remains the correction of presbyopia. 

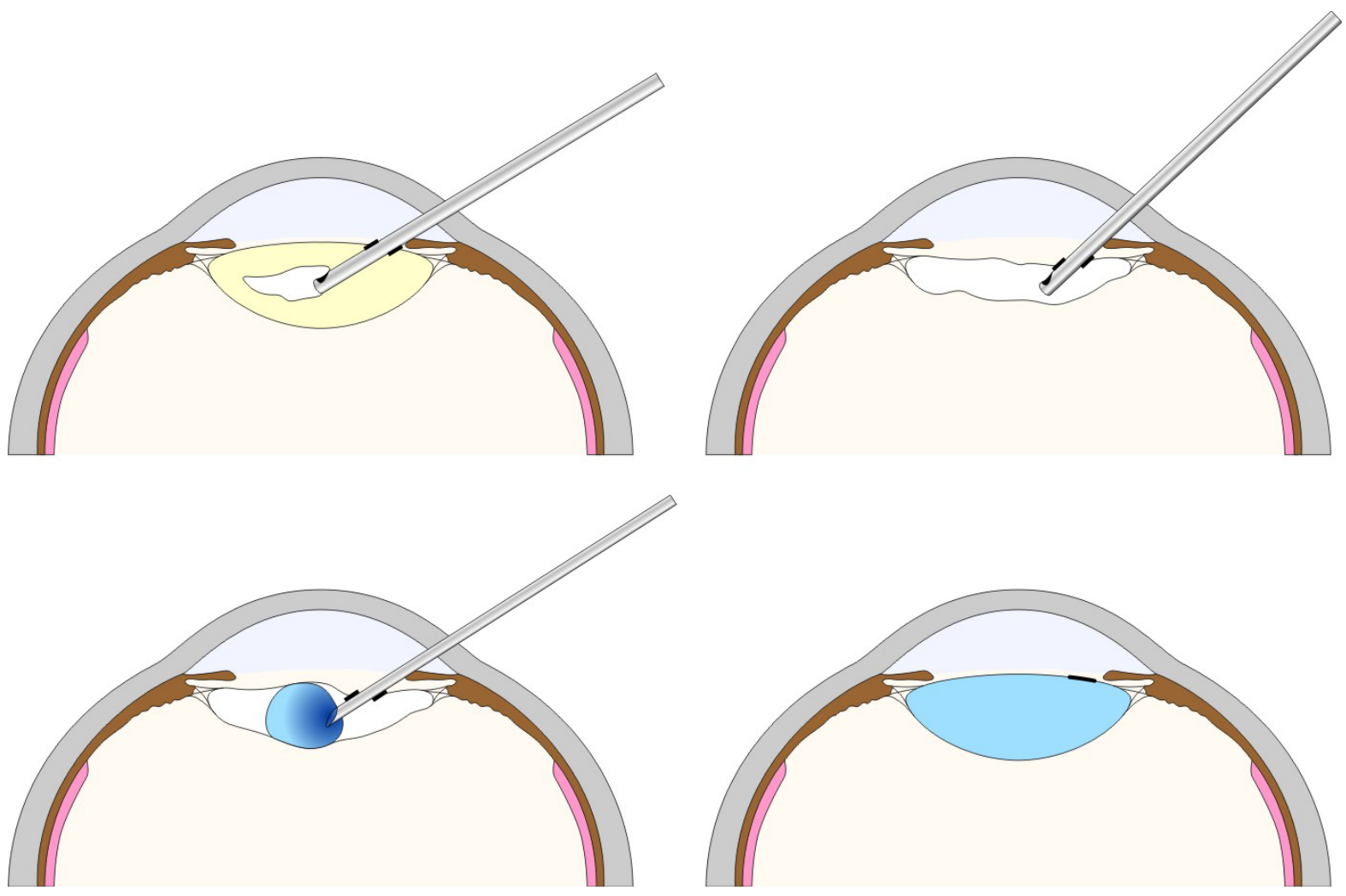

Illustration of the "lens-refilling" principle. After removal of the crystalline lens, a gel-like polymer is injected into the capsular bag instead of a foldable intraocular lens.

As the demand for the correction of presbyopia increases this will hopefully lead to the resolution of presbyopia by providing the impetus for advancing intraocular lens technology.

\section{Abbreviations}

Dpt, diopters; PMMA, Polymethylmethacrylate

\section{Acknowledgements}

The authors would like to thank graphic designer Harald Kroehn for excellent support.

\section{Disclosures}

The authors declare that they have no disclosures.

\section{References}

I. Kohnen T, Klaproth OK: Asphärische intraokularlinsen. Ophthalmologe 2008, 105:234-40.

2. Richter GM, Torres M, Choudhury F, Azen SP, Varma R: Risk factors for cortical, nuclear, posterior subcapsular, and mixed lens opacities: the Los Angeles Latino Eye Study. Ophthalmology 2012, I 19:547-54.

FlOOOPrime RECOMMENDED
3. Leske MC, Chylack LT, Wu SY: The Lens Opacities Case-Control Study. Risk factors for cataract. Arch Ophthalmol 1991, 109: 244-51.

4. Risk factors for age-related cortical, nuclear, and posterior subcapsular cataracts. The Italian-American Cataract Study Group. Am J Epidemiol 1991, 133:541-53.

5. Harding JJ, van Heyningen R: Epidemiology and risk factors for cataract. Eye (Lond) 1987, I (Pt 5):537-4I.

6. Meyer $\mathrm{CH}$, Sekundo W: Nutritional supplementation to prevent cataract formation. Dev Ophthalmol 2005, 38: 103-19.

7. Hirschberg J: Geschichte der Augenheilkunde 1908, n. p.,: n. d. v.

8. Ridley H: Intra-ocular acrylic lenses after cataract extraction. Lancet 1952, I: | | 8-21.

\section{FlOOOPrime}

\section{RECOMMENDED}

9. Kelman $C D$ : Phaco-emulsification and aspiration. A new technique of cataract removal. A preliminary report. Am J Ophthalmol 1967, 64:23-35.

\section{FlOOOPrime}

\section{RECOMMENDED}

10. Nishi O: Posterior capsule opacification. Part I: Experimental investigations. J Cataract Refract Surg 1999, 25:106-17.

II. Nishi O, Nishi K: Preventing posterior capsule opacification by creating a discontinuous sharp bend in the capsule. J Cataract Refract Surg 1999, 25:521-6. 
12. Nishi O, Nishi K, Osakabe Y: Effect of intraocular lenses on preventing posterior capsule opacification: design versus material. J Cataract Refract Surg 2004, 30:2170-6.

13. Kohnen $\mathrm{T}$ : The squared, sharp-edged optic intraocular lens design. J Cataract Refract Surg 200I, 27:485-6.

14. Ferrer-Blasco T, Montés-Micó R, Peixoto-de-Matos SC, GonzálezMéijome JM, Cerviño A: Prevalence of corneal astigmatism before cataract surgery. J Cataract Refract Surg 2009, 35:70-5.

\section{FlOOOPrime} RECOMMENDED

15. Shimizu K, Misawa A, Suzuki Y: Toric intraocular lenses: correcting astigmatism while controlling axis shift. J Cataract Refract Surg 1994, 20:523-6.

16. Mendicute J, Irigoyen C, Aramberri J, Ondarra A, Montés-Micó R: Foldable toric intraocular lens for astigmatism correction in cataract patients. J Cataract Refract Surg 2008, 34:60I-7.

17. Dardzhikova A, Shah CR, Gimbel HV: Early experience with the AcrySof toric IOL for the correction of astigmatism in cataract surgery. Can J Ophthalmol 2009, 44:269-73.

18. Silva DJ de, Ramkissoon YD, Bloom PA: Evaluation of a toric intraocular lens with a Z-haptic. J Cataract Refract Surg 2006, 32: 1492-8.

\section{FlOOOPrime}

19. Kohnen T, Klaproth OK, Bühren J: Effect of intraocular lens asphericity on quality of vision after cataract removal: an intraindividual comparison. Ophthalmology 2009, I 16:1697-706.

20. Hengerer FH, Dick HB, Conrad-Hengerer I: Clinical evaluation of an ultraviolet light adjustable intraocular lens implanted after cataract removal: eighteen months follow-up. Ophthalmology 20II, I I 8:2382-8.

\section{FlOOOPrime}

\section{RECOMMENDED}

21. Glasser A, Kaufman PL: The mechanism of accommodation in primates. Ophthalmology 1999, 106:863-72.

22. Heys KR, Cram SL, Truscott RJW: Massive increase in the stiffness of the human lens nucleus with age: the basis for presbyopia? Mol Vis 2004, 10:956-63.

23. Weeber HA, Eckert G, Pechhold W, van der Heijde RGL: Stiffness gradient in the crystalline lens. Graefes Arch Clin Exp Ophthalmol 2007, 245: 1357-66.

24. Weeber HA, van der Heijde RGL: On the relationship between lens stiffness and accommodative amplitude. Exp Eye Res 2007, 85:602-7.

25. He L, Donnelly WJ, Stevenson SB, Glasser A: Saccadic lens instability increases with accommodative stimulus in presbyopes. J Vis 2010, 10:14.1-16.

26. Evans BJW: Monovision: a review. Ophthalmic Physiol Opt 2007, 27:417-39.

\section{FlOOOPrime \\ RECOMMENDED}

27. Kohnen T, Kook D, Auffarth GU, Derhartunian V: Einsatzmöglichkeiten intraokularer Multifokallinsen und Kriterien der Patientenselektion. Ophthalmologe 2008, 105:527-32.

28. Alió JL, Plaza-Puche AB, Piñero DP, Amparo F, Rodríguez-Prats JL, Ayala MJ: Quality of life evaluation after implantation of 2 multifocal intraocular lens models and a monofocal model. J Cataract Refract Surg 201I, 37:638-48.

\section{FlOOOPrime RECOMMENDED}

29. McLeod SD: Optical principles, biomechanics, and initial clinical performance of a dual-optic accommodating intraocular lens (an American Ophthalmological Society thesis). Trans Am Ophthalmol Soc 2006, 104:437-52.
30. Ho A, Manns F, Therese Parel J: Predicting the performance of accommodating intraocular lenses using ray tracing. J Cataract Refract Surg 2006, 32:129-36.

3I. Menapace R, Findl O, Kriechbaum K, Leydolt-Koeppl C: Accommodating intraocular lenses: a critical review of present and future concepts. Graefes Arch Clin Exp Ophthalmol 2007, 245:473-89.

\section{FlOOOPrime}

\section{RECOMMENDED}

32. Klaproth OK, Titke C, Baumeister M, Kohnen T: Akkommodative Introkularlinsen-Grundlagen der klinischen Evaluation und aktuelle Ergebnisse. Klin Monbl Augenheilkd 20II, 228:666-75.

33. Seidensticker F, Schaumberger M, Ulbig M, Ludwig K, Kampik A, Lackerbauer C: Langzeiterfahrung mit einer pseudoakkommodativen Hinterkammerlinse. Klin Monbl Augenheilkd 20I0, 227:483-8.

34. Kautek W, et al., Femtosecond-Pulse Laser Ablation of Human Corneas. Appl Phys A 1994, 58:513-8.

35. Nagy Z, Takacs A, Filkorn T, Sarayba M: Initial clinical evaluation of an intraocular femtosecond laser in cataract surgery. J Refract Surg 2009, 25:1053-60.

\section{FlOOOPrime}

\section{RECOMMENDED}

36. Palanker DV, Blumenkranz MS, Andersen D, Wiltberger $M$, Marcellino G, Gooding P, Angeley D, Schuele G, Woodley B, Simoneau M, Friedman NJ, Seibel B, Batlle J, Feliz R, Talamo J, Culbertson W: Femtosecond laser-assisted cataract surgery with integrated optical coherence tomography. Sci Transl Med 2010, 2:58ra85.

\section{FlOOOPrime}

\section{RECOMMENDED}

37. Friedman NJ, Palanker DV, Schuele G, Andersen D, Marcellino G, Seibel BS, Batlle J, Feliz R, Talamo JH, Blumenkranz MS, Culbertson WW: Femtosecond laser capsulotomy. J Cataract Refract Surg 2011, 37:1189-98.

\section{FlOOOPrime \\ RECOMMENDED}

38. Nagy ZZ, Kránitz K, Takacs Al, Miháltz K, Kovács I, Knorz MC: Comparison of intraocular lens decentration parameters after femtosecond and manual capsulotomies. J Refract Surg 20II, 27:564-9.

\section{FlOOOPrime
RECOMMENDED}

39. Kránitz K, Takacs A, Miháltz K, Kovács I, Knorz MC, Nagy ZZ: Femtosecond laser capsulotomy and manual continuous curvilinear capsulorrhexis parameters and their effects on intraocular lens centration. J Refract Surg 20II, 27:558-63.

\section{FlOOOPrime}

40. Bali SJ, Hodge C, Lawless M, Roberts TV, Sutton G: Early experience with the femtosecond laser for cataract surgery. Ophthalmology 2012, I1 19:891-9.

\section{FlOOOPrime}

4I. Myers RI, Krueger RR: Novel approaches to correction of presbyopia with laser modification of the crystalline lens. J Refract Surg 1998, 14:136-9.

\section{FlOOOPrime}

42. Krueger RR, Sun XK, Stroh J, Myers R: Experimental increase in accommodative potential after neodymium: yttrium-aluminum-garnet laser photodisruption of paired cadaver lenses. Ophthalmology 200I, 108:2122-9.

43. Schumacher S, Oberheide U, Fromm M, Ripken T, Ertmer W, Gerten G, Wegener A, Lubatschowski H: Femtosecond laser 
induced flexibility change of human donor lenses. Vision Res 2009, 49:1853-9.

44. Lubatschowski H, Schumacher S, Fromm M, Wegener A, Hoffmann H, Oberheide U, Gerten G: Femtosecond lentotomy: generating gliding planes inside the crystalline lens to regain accommodation ability. J Biophotonics 2010, 3:265-8.

45. Reggiani Mello GH, Krueger RR: Femtosecond laser photodisruption of the crystalline lens for restoring accommodation. Int Ophthalmol Clin 201 I, 5 I:87-95.
46. Nishi O, Nishi K, Mano C, Ichihara M, Honda T: Controlling the capsular shape in lens refilling. Arch Ophthalmol 1997, 1 I 5:507-10.

47. Nishi $O$, Nishi $K$, Mano $C$, Ichihara $M$, Honda $T$ : Lens refilling with injectable silicone in rabbit eyes. J Cataract Refract Surg 1998, 24:975-82.

48. Nishi $Y$, Mireskandari $K$, Khaw $P$, Findl $O$ : Lens refilling to restore accommodation. J Cataract Refract Surg 2009, 35:374-82. 